\title{
Presence of Italian Language in the Albanian Education System during the Years 1800-1944
}

\author{
Albana Muceku' \\ Andomaçi Haloçi2 \\ 1. The Center for Albanian Studies \\ 2. Faculty of Foreign Language, University of Tirana, Albania; Email: albanamuceku@yahoo.com
}

Doi:10.5901/jesr.2015.v5n3p139

\begin{abstract}
This paper addresses and summarizes the presence of the Italian language in the Albanian education system from the 18th century until the 19th century. The presentation of historical facts clearly indicates that the presence of Italian language and culture in Albania is the result of a close relationship between the two countries as well as good neighborly relations, which beside all of the ups and downs, caused by various historical events, have endured the test of time. These close relations demonstrate the connection not only between the two states but also between people who throughout history have proven that they desired this connection and it has been precisely this mutual regard, which has made possible the continuity of this link. Therefore, this paper aims to demonstrate precisely that, through historical facts drawn from official documents and publications published by Albanian and foreign authors, the presence and the role Italian language had in Albania during this period.
\end{abstract}

Keywords: Italian language, the Albanian education system, Italian culture, relations, presence;

\section{Introduction}

Italy's geographical position has determined its continuous presence in Albania in different sectors of life. As a neighboring country of Albania, it follows that exchanges between the two countries have been continuous. They culminate in various historical periods which left their mark on the society and the peoples of the two countries. If we refer to historical facts, it can be said that one of the historical periods during which the presence of Italy in Albania has been the strongest dates from the late 18th century and early 19th century. In this paper I will briefly address the presence of the Italian language in the Albanian education system during these years. This paper is a summary of many historical documents taken from the official Albanian Central Archives and different publications of Albanian and foreign authors. The presentation and the highlight of these historical facts will show the presence of the Italian language before the existence of the Albanian education system, until 1944. Referring to historical facts and documents we may say that not only the Italian language but also its culture, was present in Albanian society before 1900 . This process started with the opening of the first private schools in the city of Shkodra, which taught not only the Italian language but also the history and culture of this country. Exchanges in educational and cultural sector during this period reached their peak with the establishment of the royal regime under the leadership of King Zog, who saw Italy as a strong strategic partner for development of the country. At the beginning of the new century Albania experienced a rapid increase and penetration of the Italian culture not only in the education system, but also in social life. Although facing strong rivalry from the AustroHungarian and Greek policies, Italian politics had more advantages because this movement had as its main supporter the Catholic clergy, with a strong presence throughout the country; mainly it had a stronger impact in northern Albania in the cities of Shkodra and Lezha. In addition, as a result of the operation of the Italian schools, a significant impact was observed also in other cities of Albania, such as Vlora, Durres and Gjirokastra (in the latter it clashed with Greek influences in the area). As Italy continued to strengthen its presence in the Balkan arena, it began establishing its congregations in Albania and began opening the first schools that were mainly Franciscan schools (Gogaj I., 1980).

\section{Methodology}

The objectives of this paper are the study of the presence of Italian language in the Albanian education system from 
1800 to 1944 and evaluation of the relationship between the two countries and peoples of Albania and Italy from 1800 to 1944.

Also, the study is intended to demonstrate through historical facts drawn from official documents and publications published by Albanian and foreign authors, the presence and role of the Italian language in Albania had in 1800 until 1944.

Based on objectives and aim of the present paper, this work was done in two phases: desk study and the writing and evaluation of the data taken from archives documents.

Desk study: Firstly, all previous works, which are related to presence of Italian Language in the Albanian education system, were taken into consideration. Furthermore, during of this phase, a lot of historic and culture's documents are studies in the years 2013-2015 in many libraries and Albanian archives. These institutions were the source of many historical official documents which were thoroughly read and analyzed, and also many publications of Albanian and foreign authors were reviewed.

Writing and evaluation of the data: Referring to the facts presented in those publications and historical documents, it becomes clear that there was a strong presence and influence of Italian language in the Albanian education system during the years 1800-1944, and for the purpose of analysis this presence was grouped into three categories, which are i) the presence of the Italian language in non-public schools, ii) Italian School for boys and girls (elementary), iii) The presence of the Italian language in public schools in the years 1920-1940.

\section{Italian Language in the Albanian Education System, in the Years 1800-1944}

This article summarizes a vast and detailed amount of work conducted in the years 2013-2015 in many libraries and Albanian archives. These institutions were the source of many historical official documents which were thoroughly read and analyzed, and also many publications of Albanian and foreign authors were reviewed. Referring to the facts presented in those publications and historical documents, it becomes clear that there was a strong presence and influence of Italian language in the Albanian education system during the years 1800-1944, and for the purpose of analysis this presence may be grouped into three categories, which are presented below.

\subsection{The presence of the Italian language in non-public schools}

\subsubsection{Schools in the city of Shkodra}

Given the lead of the Catholic clergy and early relations between Shkodra and Italy in all areas, the first schools in Albania in which students learn the Italian language begin long before the period after independence.

Mainly the first schools where students were taught the Italian language were among the private school. The first such school was founded by Geg Kodheli in 1830 where students learned the Italian language. The desire and willingness to teach Albanian children Italian language and culture pushed George Benuss to open his school (school which carried his name) in 1836. Primarily this school was attended by children of merchants who by learning the Italian language would use it to easier develop trade relations and further their education in Italy. This tradition was carried further by his son, who along with his father led the school by publishing a primer published in Bucharest at the end of which is a small Italian-Albanian dictionary and examples of commercial correspondences of merchant families in Shkodra (S. Bala, 2011). The Franciscan school opened in 1861. This was the first school which was open to the public and for its benefit in order to teach and educate their children.

A report by the Austrian consul read: "the main courses taught were religion, grammar, Italian, mathematics and calligraphy. Lessons were taught in four classes "(S. Bala, 2011). The activity of this school was developed further. Within a short time it added classes which went from two to three in each parallel and in 1902 added the middle citizen school. During this year the school counted the Franciscan College, saurian-Jesuit, a primary school with 5 classes, a real school with 3 classes and trade school with three classes. The same year the evening school opened which was frequented by various apprentices and workers. The learning of Italian language in this school became more consolidated and it further developed from simpy learning to speak the language to the study of Italian grammar. However it should be noted that all other subjects were taught in Albanian language and so this school has been among the first to introduce the Albanian language learning courses (S. Bala, 2011). In 1921, the school changed its name and was called "Franciscan High School" to adapt to the changes that occurred in the educational system in Albania at the time. Later it was called "The School Illiricum". This school was led by popular and well recognized figures of that period 
such as Gjergj Fishta, Vinçens Prendushi, Pader Donald Kurti, and many other personalities who shared their knowledge and commitment with students in this school.

\subsubsection{Saverian College}

This college opened on October 17, 1877 and its founder was Father Luigji Mazza. The school taught classes in Albanian but one of the main subjects was the Italian language. Italian language was highly in demand by people who saw it as a tool in assisting them for the development of trade relations they had with Italy. This was the reason the first classes that opened they were of a commercial and technical nature (3 commercial and 3 technical). Later, in 1926, the college changes its profile and goes back to being a grammar school. In this college Albanian language was taught as a separate subject alongside Italian, German, French and other subjects deemed necessary for the general education.

The contribution offered by teachers and different personalities who worked at this college was different; e.g. during their work on the upbringing and education of Albanian children, they published various dictionaries of AlbanianItalian, as the one by Jak Junku which contained about 12,000 words. This college was run by Ndre Mjeda, Father Peter Meshkalla etc. (S. Bala, 2011). Besides the education of boys, an important place of the education system in Shkodra was the education of girls. The first girl's school opened in this city was founded by the Stigmatine Sisters in 1879 and functioned as primary, secondary and later as a middle school. In this school, in the lower grades the instruction was given in Albanian, while in the higher classes the language was both, Italian and Albanian. The demand from girls to join this school was very high and constant. The Government granted scholarships to students from other districts of the country both domestically and abroad as from Elbasan, Korca, Tirana, Tivar and Cetina etc. (S. Bala, 2011).

\subsubsection{Professional Schools}

Agreements made in the educational field were the result of improvements in the current state of education in Albania. On June 28, 1928 the Italian and Albanian government signed an agreement for the establishment of vocational schools which were to be headed by Italian personnel and Italians would also supply the teaching material. Recognizing the country's need for specialized workers, the Albanian Government signed an agreement which would be implemented in three phases the result of which would the opening of 9 vocational schools. In the first phase these schools would open in Berat, Gjirokastra, Korca and Shkodra. The Ministry of Education created a new section which would oversee these schools. Mr. P. Lurasi was named the head of this department. The financing vocational school was done fully by the Italian government (Bala S., 2011).

The objective of these schools was (i) preparation of specialized workers as craftsmen, technicians and several other crafts that would help develop the economy of the country and (ii) dissemination of Italian culture and civilization.

On January 3, 1929 the vocational school of Gjirokastra opened, which was followed by the opening of schools in other cities which were scheduled to open, such as the school in Berat, Korca, and a few months later (October 1, 1929) opened the industrial school and that of applied arts in Shkodra. Schools of Berat and Gjirokastra consisted of 4 year schooling on top of the elementary education focusing mainly in industrial and artisanal training. These schools prepared locksmiths, mechanics, and electricians. They offered practical courses for technicians which took place in the afternoon and were of a more practical character. Students in these schools could not attend universities. While the schools of Shkodra and Korca, were more complete professional schools. They consisted of 2 cycles of 4 years each. During the first year of school all students took preparation classes. The all instruction in that first year was given in Italian language so that the students could master it better and adapt to it. These schools prepared surveyors, technicians, radiotechnicians etc.

These schools were equipped with workshops and joinery cabinets fitted with numerous machinery and equipment which were financed by the Italian government. Teaching staff in these schools was almost entirely Italian. Also, the schools were well equipped with rich libraries that could be used by students for learning about Italian culture and civilization. The uniqueness of these schools was that they were attended mainly by students from poor families (especially the schools of Gjirokastra and Berat). Everything that students used was free, even the books. There were cases when the Albanian government in cooperation with the Italian government awarded the scholarship and a meal plan in the canteen (2 times a day) for children of families in need. Getting their children into these schools for many of these families was a solution for the education of their children. The pedagogical basis of these schools was that of the "work school" which was intended to prepare students by focusing on the practical learning. Very soon it was observed that the students themselves enjoyed the style of this schooling and they worked with dedication and desire. So they 
organized the first exhibitions of their craft products many of which were shipped even abroad as for example in East Fair in Bari. These original products of the students demonstrated the capacity and productivity of these schools which served as a model for the preparation of skilled workers.

The second phase of the extended agreement aimed at enhancing these schools across the country.

Italy aimed to reorganize the profiles and expansion of these schools. But in late 1932 and early 1933 the Albanian Ministry of Education took a series of measures, among which those stipulated that:

All foreign teachers teaching in these schools would sign a binding a legal contract with the Albanian Ministry of Education (archival documents, 1936 a).

Teaching in these schools could not be done in a foreign language without a special permission from the Ministry of Education and all other subjects were to be taught by Albanian teachers in Albanian (archival documents, 1936 a).

First four professional schools would henceforth be were dependent directly from the department of vocational education.

Along with the Italian director schools would also have a managing Albanian director.

Italian director would report directly to the high school department of the Ministry.

The government at the time it took such actions did not intend the closure and the expulsion of the Italian teachers from Albania but it wanted Ministry of Education to oversee these schools. Thereafter vocational schools were run by Italians and Albanians. As a result of disputes and conflicts arising during the running and management of the school, the contingent of Italian teachers fled from Albania. After they left, school funding became more complicated because the Albanian government was poor and unable to fund these schools properly so the result was their closing, late 1932-1933 (Bala S., 2011).

\subsection{Italian School for boys and girls (elementary)}

Elementary schools opened in the early -20's mainly in Vlora and Shkodra (Franciscans, saverians and stigmatins) in late 1924 there was a large increase in their number. This was the result of the demands by rich strata of population in the country who wanted their children's education to be better. Thus such schools were opened in Durres and Tirana. Unlike other elementary schools, the Tirana school was opened with the decision of the Albanian government. It was managed by an Albanian director and it qualified as an Albanian-Italian school. While other elementary schools such as those of Durres, Vlora and Shkodra were managed and financed directly by the Italian government. These schools included also kindergartens and taught home economics courses for girls. Catholic Church was very much present in these schools and collaborated closely with the Italian government, as is the case of schools in Shkodra or the primary school in Durres, which in its inception was opened by nuns with the support of the Italian Embassy in Albania. Also during 1930 in Tirana opened a Jesuit school. All the schools which were directly financed by the Italian government had an Italian teaching body, with the exception of nuns who played a significant role in these institutions. The number of students in these schools was increasingly growing. These schools were attended not only by Albanian children but also by the children of Italian families who worked and lived in Albania.

\subsection{The presence of the Italian language in public schools in the years 1920-1940}

In Albania at the time the introduction of foreign languages in secondary schools was a necessity because the scientific literature in Albanian language was quite limited and many times lacking. Italian Language during that period, in contrast to other foreign languages was required in schools with the insistence of the Italian government and its diplomatic representation in Albania. In the years 1929-1930 the Ministry of Education asked all public high schools to develop a weekly school program scheduling the hours dedicated to learning Italian language and list the teachers who would take over these classes. In case the number of teachers was not enough to fill those spots this framework would be complemented by teachers who were to come from Italy. During the school years 1930-1931 the number of hours dedicated to teaching Italian language did drastically increase. It became the language most requested by students of lower classes. Viewing the preference and choice that students showed for this language the number of instructors teaching Italian increased and the majority of them came from Italy (Gogaj I., 1980). These teachers were paid by the Italian government. In comparison with other foreign languages like German, French and English, Italian was at the top of the list. At this time the Government and the Ministry of Education promulgated the "Regulations on the teaching of foreign languages in schools" Article 2 stated: 
"Of the four foreign languages which should be studied in commercial and technical and general education schools, the teaching of Italian language is compulsory for all students of secondary schools and trade schools starting in third grade. They will learn Italian and also another foreign language to be chosen by the students "(Gogaj I., 1980).

In some public schools such as the trade school in Vlora, presence of Italian language was stronger because in addition to the study of language, most subjects in this school in the majority of cases (professional), were held in Italian with Italian professors.

Also another school where Italian language was given priority was the middle school of Elbasan. Compared to other public schools, this institution dedicated more hours to learning Italian language. The reason for that was that the majority of students who graduated from this school went on to continue their studies in Italian universities with scholarships mostly funded by the Italian Government or by the Albanian government.

\subsection{The influence of Italian language in the cultural formation of the young people from attending higher studies in Italy in the years 1920-1944}

In addition to opening schools and spreading Italian culture and Italian language through didactic forms made available by the Italian government, the number of students who wanted to study in Italy was growing. Based on the correspondence of numerous persons we may observe the large number of requests by Albanian students who wanted to continue their studies or even secondary schools in Italy. The main subjects most in demand by young Albanians varied and they corresponded to country's needs to prepare specialists in various sectors such as medicine, engineering, law, economics, commerce, pharmacy, military school etc. While attending these schools other than language students were introduced to the culture and traditions of the Italian people. Universities followed closely the academic progress, attendance and behavior of these students. As far as Albanian students attending secondary schools in Italy the care and attention towards them was greater. They maintained constant correspondence by regularly notifying the families regarding their results and behavior. In 1929 there was an increase in the number of the young people who wanted to carry out their studies, secondary education or even religious education in Italy (archival documents, $1930 \mathrm{a}$ ). Only in 1930 the number of young Albanians who had studied in Italy was 120, who had full scholarships provided by the Italian government. Also a large number of young people studied in Italy who performed specialized courses of 6 months or a year as those cheese processing (archival documents, 1924, 1930b and 1936b). There was great support for the promotion and dissemination of education in Italy of the Albanian pupils and students, from the Albanian government in the years 1920-1942. The Ministry of Education and respective high school inspectorates in Albania Albanian youth recognized university programs with faculty bulletins and other information transmitted periodically by the Ministry of Education of the time (archival documents, 1936c).

\section{Conclusions}

Well-documented presence of Italian language in Albanian education system was the result of intensification of relations between the two countries. These relations were observed in different areas and had a major impact on the life of every citizen. In the education area along with the language the Italian culture was also spread throughout the country. This promulgation was observed from the earlier educational levels: elementary, middle and secondary; in Albanian public schools as well as the foreign private, religious and professional schools, even in two-year schools. Vocational schools employed many Italian teachers who in addition to teaching general subjects to Albanian pupils, taught them crafts and profession but also the importance of good work ethic.

This campaign was massively approved by the Albanian people, especially by the poor strata of the population which considered this kind of education as the only possibility for the education of their children.

Italy in these years was regarded as the country which offered more for Albanians. This fact is supported by the interest indicated from a higher number of pupils and students in particular those students who continued their studies in different cities of Italy. These students by mastering the language and studying in those schools also became conveyors of a European culture which would help in the development of our country.

\section{References}

Archival document, (1924). Durres and Italians. Savings account no. 163, file 196. Central State Archive in Tirana, Albania, p. 3-7.

Archival document, (1930 a). Correspondence with the prefecture of Berat, Durres, Shkodra and Tirana for studies purpose of 
secondary, higher and religious schools in Italy and other countries. Documents no. 620,624, 626, 627. Savings account no. 195. Central State Archive in Tirana, Albania.

Archival document, (1930 b). Durres and Italians. Savings account no. 163, file 411. Central State Archive in Tirana, Albania, p. $22-25$. Archival document (1936 a). Article no. 8 and 9. Official bulletin no. 29, dated 9.5 1936. Central Archive in Tirana, Albania.

Archival document, (1936 b). Correspondence of the Education Ministry and Ministry of Foreign Affairs with the Italian Legation in Durres. Savings account no. 263, file no. 411, savings account no. 163, file 175 and savings account no. 195 with file 451. Central State Archive in Tirana, Albania.

Archival document, (1936 c). Savings account no. 195, file no. 193. Central State Archive in Tirana, Albania.

Bala S., (2011). History of schools and teachers in Shkodra Town. Volume no.1, Publishing House "Rozafa" Tirana, Albania, p. 111-175.

Gogaj I., (1980 a). Italian educational intervention in Albania and the resistance against it until 1939 year. The publishing house "8 Nëntori", Tirana, Albania, p. 9-95. 